\title{
Anna Kościołek, Andrzeja Murawjowa peregrynacje do kolebek chrześcijaństwa (Jerozolima, Rzym, Kijów), Wydawnictwo Naukowe Uniwersytetu Mikołaja Kopernika, Toruń 2020, ss. 334
}

Dobrze mieć w ręku książkę, a nie tylko PDF wyświetlony na ekranie — książkę erudycyjną, rzetelnie, a przy okazji, co może wydawać się prawie niemożliwe w przypadku dzieł naukowych, ciekawą, wciągającą. Lekturę książki Anny Kościołek uprzyjemnia piękna polszczyzna, jaką monografia jest pisana. Andrzeja Murawjowa peregrynacje do kolebek chrześcijaństwa... wtajemniczają polskiego czytelnika w świat miniony, XIX-wieczny, widziany przez Rosjanina, żarliwie wyznającego wiarę w Chrystusa, ale wiarę prawosławną. Dekadę temu badałam XIX-wieczne pielgrzymki przede wszystkim Polaków, katolików, toteż wielkim dla mnie intelektualnym doświadczeniem i przygodą było poznać perspektywę odmienną — percepcję Ziemi Świętej przez obywatela zaborczej Rosji carskiej i przedstawiciela prawosławia. Taka opcja zaciekawi też innych filologów z racji nowatorskiego wkładu Anny Kościołek w poszerzanie wiedzy na temat Andrieja Murawjowa i na temat odbioru miejsc świętych przez tegoż poetę, pisarza, społecznika. Aby polski czytelnik mógł poznać bogactwo kultury i natury Jerozolimy, Rzymu i Kijowa, przyswojone przez wrażliwą umysłowość Murawjowa, toruńska slawistka napisała monografię po polsku - zostawiając tylko poezje i niewielkie fragmenty prozy w języku oryginału. Autorka musiała przestudiować ogrom materiału (zwłaszcza tzw. egodokumentów), przede wszystkim w wersji rosyjskojęzycznej, ale także polskojęzycznej. Streszczanie, parafrazowanie, wyprowadzanie wniosków przebiega w jej obszernej pracy w sposób transparentny, naturalny, niezauważalny „dla oka”: narracja w obrębie poszczególnych części i rozdziałów płynie harmonijnie, logicznie, w miarę konieczności przeplatana bywa cytatami ze wspomnień, listów tytułowego bohatera bądź z dzieł naukowych innych badaczy; wzbogacana też bywa raz po raz poezją Murawjowa. Nie ma przesytu cytatów w tym dziele — wszystko pozostaje w należnych proporcjach. 
Autorka zaczyna od bardzo szczegółowych określeń i definicji pielgrzymki, jej roli w życiu wierzących, szczególnie chrześcijan. Do współczesnych definicji odnosi się w sposób następujący: „Współcześnie pielgrzymkę można określić jako akt pobożności polegający na ruchu w przestrzeni i czasie. Istnieje wiele definicji peregrynacji, ich autorzy wychodzą z różnych założeń, uwypuklają te elementy, które są szczególnie ważne z punktu widzenia uprawianych przez nich dyscyplin naukowych. W tych rozmaitych ujęciach można wyróżnić kilka najważniejszych elementów. Po pierwsze pielgrzymka to akt natury religijnej (może to być praktyka zarówno zbiorowa, jak i indywidualna). Po drugie, osobę ją podejmującą cechuje dążenie do kontaktu ze sferą transcendentną. Po trzecie, istotną rolę odgrywają osobiste przeżycia pątnika (s. 10; podkreślenie moje - D.K.). Badaczka bardzo dobrze określa stan badań, choć zabrakło chyba - jako kontekstu interpretacyjnego - niektórych prac z pątnictwa polskiego i o peregrynacjach polskich (np. Europejczyk w podróży 1850-1939, pod red. nauk. Ewy Ihnatowicz i Stefana Ciary, Warszawa 2010) czy europejskich — w tym ruskich i rosyjskich (Danuše Kšicová, Cesty do Svaté zeméXII. -XX. století: Mýty a realita v ruských a českých cestopisech, Masarykova univerzita Brno 2013, stron 336). Nie ma w nich mowy o Murawjowie, ale właśnie to jest znaczące — gdyż szczególnie w tej drugiej pozycji, nieżyjącej już slawistki z Brna, powinny takie informacje się znaleźć. Zabrakło mi również odniesień do najwierniejszego wśród Polaków czytelnika dzieł podróżniczych Andrieja Murawjowa, a za jego pośrednictwem Ihumena Daniela - ks. Ignacego Hołowińskiego, autora Pielgrzymki do Ziemi Świętej. Nie wiadomo, czy ten niezwykle wykształcony i płodny artystycznie ksiądz katolicki znał osobiście prawosławnego apologetę chrystianizmu. Łączył ich Kijów, gdzie Murawjow był już w 1823 roku, ale osiadł na stałe dopiero w 1858 roku. Natomiast Ignacy Hołowiński od 1837 roku był profesorem na Uniwersytecie Kijowskim i tamtejszym kapelanem. Oczywiście brak wspomnienia o czytelniku Murawjowa nie umniejsza walorów pracy naukowej, gdyż jest ona o miastach świętych w życiu i twórczości Rosjanina, a nie o koneksjach czy o dziejach ówczesnej bądź późniejszej recepcji jego dzieł.

W pierwszym rozdziale autorka przypomina tradycję pielgrzymowania w kulturze europejskiej. Spektrum zainteresowania nie ogranicza tylko do chrześcijaństwa, a w jego obrębie do prawosławia, lecz pisze o peregrynacjach we wszystkich wielkich religiach świata. Zarysowuje różnicę między tradycją bizantyjską a łacińską. W drugim rozdziale Anna Kościołek przybliża polskiemu czytelnikowi biografię Murawjowa, posiłkując się przy tym jego egodokumentami (wspomnieniami, korespondencją). Trzeci rozdział poświęcony jest Jerozolimie. Święte miasto żydów, muzułmanów i chrześcijan wyłania się z zapisków uczynionych przede wszystkim w Podróży do Ziemi Świętej w 1930 roku (wyd. 1832), a także odgrywających rolę uzupełnienia Listów ze Wschodu w latach 1849-1850, wydanych w 1851 roku. Dla polskich czytelników rozważania te są cenne, gdyż za mało chyba jeszcze wiemy o związkach Rusi czy Rosji z Palestyną. Anna Kościołek nam te kwestie kompetentnie przybliża. Roma christiana (obiekty sakralne) i Roma pogana (zabytki antyczne) obecne u Murawjowa i w ogóle w literaturze rosyjskiej stanowią temat dociekań w rozdziale czwartym. Interesująca jest tu prezentacja stosunku poety do papiestwa i katolicyzmu. W rozdziale piątym autorka prezentuje kolebkę chrześcijaństwa ruskiego - Kijów. Autor i w tych opisach, a nie tylko w deskrypcji Jeruzalem, posiłkował się średniowiecznymi pismami ihumena Daniela.

Pod koniec wstępu Anna Kościołek pisze o metodologiach i „podejściu interdyscyplinarnym”. Deklaruje „różne strategie metodologiczne: psychologiczno-biograficzną, semiotyczną, intertekstualność, geopoetykę, ustalenia z zakresu geografii humanistycznej i geografii 
religii” (s. 18), nie rozwija jednak wątku teorii oraz metod — i słusznie, gdyż przedmiotem badań jest twórczość Murawjowa nakierowana na recepcję miejsc świętych, a nie metodologia jako taka, rozwijana dla niej samej. Ważne jest jednak, że polskiemu czytelnikowi badaczka przybliża pojęcie doświadczenia liminoidalnego, utworzone przez amerykańskiego antropologa i religioznawcę Victora Turnera. Jako religijne doświadczenia liminoidalne i jako „ryty przejścia” (za Arnoldem van Gennepem) Anna Kościołek postrzega pielgrzymki do miejsc świętych (s. 98 i in.). Powołuje się też na Małgorzatę Czermińską i jej koncepcję miejsc autobiograficznych (s. 108).

Wchodząc w tajemniczy świat XIX-wiecznej przeszłości, autorka dokonuje przenikliwego rozeznania w kwestiach ówczesnych obyczajów. Daje szeroki rys historyczny. Nieraz oznajmia rzeczy zdumiewające, np. gdy powołując się na ustalenia innych naukowców, pisze o nie zawsze religijnych i zacnych celach pielgrzymek: „W średniowieczu wielu pątników zostawało bandytami, oddawało się pijaństwu albo rozpuście. Miejsca pielgrzymkowe zamieniały się w hałaśliwe jarmarki” (s. 42).

Informacje o Andrzeju Murawjowie, przynajmniej w chwili powstawania tej recenzji, nie istnieją w polskiej przestrzeni wirtualnej. Nie ma nawet o nim informacji w popularnej Wikipedii, w odróżnieniu od bardzo bogatych źródeł rosyjskich. Być może sytuacja niedługo się zmieni, gdyż dzięki Annie Kościołek wiemy już o wiele więcej o autorze Historii miasta świętego Jerozolimy od czasów apostolskich do naszych (1844). Wiemy też, że przede wszystkim pozostał poetą, co nie było oczywiste dla znawców jego dzieł peregrynacyjnych czy ogólnie: religijnych i teologicznych ${ }^{1}$.

Autorka Andrzeja Murawjowa peregrynacji do kolebek chrześcijaństwa... zgłębiając wiedzę na temat Murawjowa, wyruszała na różne kwerendy, zjazdy, konferencje, a zanim wydała recenzowaną niniejszym monografię, napisała kilka artykułów o bohaterze swoich dociekań. Bardzo dobrze prześledziła stan badań polskich i zagranicznych, zapoznała się z pracami: habilitacyjną Iriny Moklecowej (zob. s. 103-104) i doktorską Oleksandry Pobierieżnik (s. 104-105) oraz ich artykułami. Szczególnie bliskie są jej badania częstochowskiego środowiska naukowego, zwłaszcza prace historyczne Norberta Morawca oraz slawistyczne Urszuli Cierniak. Ta ostatnia szczególnie uwrażliwiła autorkę monografii na problem polemiki prawosławnego pisarza z katolicyzmem i jego uwag wobec Kościoła Łacińskiego. Niejako wraz z Urszulą Cierniak badaczka śledzi liczne zarzuty Murawjowa pod adresem władzy papieskiej, rozciągającej się z Watykanu na cały świat, oraz pod adresem katolicyzmu (s. 194 i nn.). Wątek ten jest bardzo ciekawy — odsłania spojrzenie na papiestwo XIX wieku z innej strony niż katolicka. Oczywiście nie znaczy to, że sądy Murawjowa są obiektywne. Są po prostu inne: „Doszedł do wniosku, że prawosławie jest głębsze i bardziej wewnętrzne niż katolicyzm” (s. 195). Nie mógł przeboleć, że niektórzy porzucili „wiarę ojców” i jak Zinaida Wołkońska dokonali konwersji na katolicyzm. Autorka widzi niekonsekwencję w antypapieskim nastawieniu Murawjowa: „Warto przypomnieć, że na Rusi, a potem w Rosji czczono niektórych biskupów Rzymu, na przykład Klemensa I, Leona I Wielkiego oraz

1 Jednym z takich miejsc towarzyskich pogawędek był moskiewski salon Zinaidy Wołkońskiej — konwertytki na katolicyzm; notabene przyjaciółki również naszego arcypoety - Adama Mickiewicza. Warto byłoby kiedyś sprawdzić, czy Murawjow poznał się wówczas z Mickiewiczem i w jaki sposób układała się znajomość między dwoma poetami. Niesamowita była wiedza Murawjowa: znał pięć języków nowożytnych (niemiecki, francuski, angielski, włoski, arabski) i dwa starożytne (grekę i łacinę). Swoją bogatą, niezwykle intensywnie przeżytą egzystencję zakończył po kolejnej pielgrzymce na górę Athos i chorobie - latem 1874 roku. Badaczka przypomina nam, że w Polsce bardziej jest znany jego brat — Michał Murawjow — słynny „Wieszatiel”. 
Grzegorza I Wielkiego, nazywanego Dialogiem, papieży przed rozłamem Kościoła” (s. 201; por. s. 213). Trzeba z drugiej strony zauważyć, że ów poeta, „obrońca prawosławia” przez całe lata istnienia komunizmu był w Rosji i ZSRR „tematem” zakazanym. Dopiero druga połowa XX wieku otworzyła możliwości badania jego życia i twórczości.

Nowatorstwo pracy z 2020 roku polega na skupieniu uwagi na literaturze, na wątkach i tematach peregrynacyjnych, rozważanych również w aspekcie komparatystycznym (por. s. 107). Autorka dostarcza wielu informacji o obyczajowości chrześcijańskiej i o podziwianej przez Murawjowa architekturze sakralnej, posługując się przy tym specjalistycznym słownictwem. Umiejętnie streszcza i wplata do swojej narracji zapomniane legendy chrześcijańskie. Kiedy opisywane są obrazy i rzeźby, aż się prosi, by badaczka dostarczyła ilustracji, nie wszyscy bowiem znają reprodukcje, a tym bardziej nie wszyscy byli w tych miejscach, które miał szczęście zwiedzić pobożny bohater.

Zawsze pod koniec czy to rozdziału o Jerozolimie, czy o Rzymie, czy o Kijowie slawistka przechodzi od najbardziej fascynującej Murawjowa tematyki sakralnej i religijnej do zagadnień związanych z tamtejszym pięknem przyrody, na które poeta był równie wrażliwy. Książka opatrzona została bogatą bibliografią i indeksem osobowym.

Anna Kościołek zapełnia poważną lukę w naukach humanistycznych. Swoją narrację prowadzi, posługując się nienaganną polszczyzną. Naukowy styl niemal zupełnie wyklucza subiektywne podejście, chociaż zdarzają się miejsca, w których autorka dyskretnie, z lekką ironią i z przymrużeniem oka pisze o swoim bohaterze jak o bliskiej sobie osobie. Nic dziwnego: przez wiele lat obcowała z jego dziełami, z jego myślą pozostawioną w jego ojczystym języku na kartach wspomnień, listów, tomików poezji itd. Ma więc prawo wyrażać się o nim z pewną poufałością, ale tego prawa bynajmniej nie nadużywa, zachowując naukowy dystans.

Autorka bardzo rzetelnie podeszła do tematu, z wielką uwagą przebadała rosyjskojęzyczne teksty, wniknęła w rosyjską kulturę i prawosławną mentalność. Napisała książkę piękną, która na długie lata będzie służyć znawcom i koneserom XIX-wiecznych pielgrzymek, miłośnikom sztuki sakralnej. Anna Kościołek nie podporządkowuje wyznawczo dyskursu żadnej teorii, ale po prostu prezentuje wyniki swoich filologicznych (a przy okazji: historycznych, architektonicznych, teologicznych, geograficznych itd.) badań. Interdyscyplinarność nie szkodzi narracji, tylko ją wzbogaca. Monografię czyta się jako niezłą opowieść biograficzną, książkę podróżniczą, przewodnik po miejscach świętych, przewodnik historyczno-turystyczny, reportaż, a także dzieło komparatystyczne osadzające teksty Murawjowa w przestrzeni innych dzieł literatury powszechnej. Mistrzostwem autorki jest zachowanie stylu naukowego i wykazanie wysokiego poziomu erudycji (oczytanie w literaturze rosyjsko- i polskojęzycznej) przy równoczesnej „dostępności” tego studium umysłom szerokiej rzeszy potencjalnych czytelników. Lektura monografii dostarcza intelektualnej przyjemności - Barthesowskiej „przyjemności tekstu”. Książkę oceniam jako potrzebną nie tylko polskiej nauce; w recepcji nienastręczającą większych problemów, pisaną przystępnym językiem, fascynującą również dzięki pogłębionej problematyce z dziedziny sacrum. 